\title{
Introduction: Autochthonous human adaptation to biodiversity change in the Anthropocene
}

\author{
Patricia L. Howard, Gretta T. Pecl
}

Published online: 23 November 2019

\begin{abstract}
Rapid biodiversity change that is already occurring across the globe is accelerating, with major and often negative consequences for human well-being. Biodiversity change is partly driven by climate change, but it has many other interacting drivers that are also driving human adaptation, including invasive species, landuse change, pollution and overexploitation. Humans are adapting to changes in well-being that are related with these biodiversity drivers and other forces and pressures. Adaptation, in turn, has feedbacks both for biodiversity change and human well-being; however, to date, these processes have received little science or policy attention. This Special Issue introduces human adaptation to biodiversity change as a science-policy issue. Research on human adaptation to biodiversity change requires new methods and tools as well as conceptual evolution, as social-ecological systems and environmental change adaptation approaches must be reconsidered when they are applied to different processes and contexts-where biodiversity change drivers are highly significant, where people are responding principally to changes in species, species communities and related ecosystem processes, and where adaptation entails changes in the management of biodiversity and related resource use regimes. The research was carried out in different marine and terrestrial environments across the globe. All of the studies consider adaptation among highly biodiversity-reliant populations, including Indigenous Peoples in the Americas and Europe, farmers in Asia and marine resource users in Europe and the Pacific. The concept of autochthonous adaptation is introduced to specifically address adaptation to environmental change in local systems, which also considers that local adaptation is conditioned by multiscalar influences and occurs in synergy or conflict with
\end{abstract}

adaptations of other non-local agents and actors who enable or constrain autochthonous adaptation options.

Keywords Autochthonous adaptation .

Biodiversity change $\cdot$ Case studies .

Conceptual frameworks

\section{INTRODUCTION}

Multiple drivers, including climate change and other anthropogenic stressors, are forcing rapid biodiversity change across the globe (MEA 2005; Ichii et al. 2019). This rapid change is also the outcome of human adaptation to biodiversity change, which affects both the drivers of biodiversity change and creates new feedbacks with both intentional and unintentional consequences for ecosystems and human well-being. Human adaptation to biodiversity change can lead to regime shifts and intentional transformation (Howard 2019). However, human adaptation to biodiversity change is not yet considered in international, regional or national policy or science forums, not even in the Intergovernmental Policy-Science Platform on Biodiversity and Ecosystem Services (IPBES), which otherwise integrates the multiplicity of human values, indigenous and local knowledge and good quality of life within its framework (Díaz et al. 2015; Pascual et al. 2017). In part this is because, while both adaptation and biodiversity change are research topics, human adaptation to biodiversity change is not "a 'scientific problem'-a field of theorising or methods development" (Howard 2019). Policy makers and scientists thus lack conceptual frameworks, knowledge and tools to understand or predict human responses and their actual or potential outcomes, synergies and feedbacks in terms of human welfare, biodiversity, 
social-ecological systems and climate change mitigation and adaptation (Howard 2009). For these reasons, from 2011 to 2012, the Ecosystem Services and Poverty Alleviation Programme (ESPA) of the UK Government funded the first research project on this theme, entitled 'Human adaptation to biodiversity change: building and testing concepts, methods, and tools for understanding and supporting autonomous adaptation' (referred to in several papers in this Special Issue as 'HABC'). ${ }^{1}$

Human adaptation to biodiversity change is a response to changes in the web of life affecting human well-being (Naeem et al. 2016). Given humanity's global range, we are the only species that is reliant on the full range of ecosystem services that biodiversity provides (Ellis 2011; Chaplin-Kramer et al. 2019) and the only species that, through our actions, can alter biodiversity change processes from local to global levels (Ellis 2011; Boivin et al. 2016; Bull and Maron 2016). Biodiversity change will certainly have negative consequences for all human societies, current and future, but the implications are particularly dire for those living in regions where biodiversity change is expected to be greatest (tropical forest, tropical woodland, savannah and warm mixed forest) (Van Vuuren et al. 2006), and for those who directly depend on biodiversity for their livelihoods and cultural integrity, including farmers, pastoralists, forest peoples and fishers, as well as all allied industries (Pecl et al. 2017). Even small changes in local biodiversity can lead to major threats to the availability of food, fuel, fibre, construction materials, medicines and other plant, animal and marine resources (e.g. Bell et al. 2013; Hanewinkel et al. 2013; Campbell et al. 2016). Climate change interacts with all other biodiversity stressors, any or all of which can push socioecological systems across tipping points (MEA 2005; Scheffer 2009; Howard 2013; Gaertner et al. 2014; Leadley et al. 2014; Vasilakopoulos et al. 2017). Biodiversity change affects each region, sub-region and social-ecological system differently. Humans have adapted and will continue to adapt across all major world biomes and productive systems (see e.g. Howard 2009; Shaw and Osborne 2011; Bebber et al. 2013; Ding and Nunes 2014; Peters et al. 2014; Pecl et al. 2017; Yan et al. 2017; Manners and van Etten 2018; Ichii et al. 2019).

\footnotetext{
${ }^{1}$ See https://www.espa.ac.uk/projects/ne-i004149-1. Several of the papers published in this Special Issue were developed for the Centre for Biocultural Diversity (University of Kent) symposium, 'Climate Change, Biodiversity and Human Adaptation' at the Royal Anthropological Institute Conference, 'Anthropology, Weather, Climate Change', London, 27-29 March, 2016 (https://research.kent.ac.uk/ $\mathrm{cbcd} /$ news/?article $=2025$ ).
}

\section{THE STUDIES: EMPIRICAL BREADTH AND DEPTH}

The papers in this Special Issue span a large diversity of marine and terrestrial biomes, and different anthromes (Ellis 2011), in developed, emerging and developing economies. Several cases focus on Indigenous Peoples in each of these contexts, including in Norway, North and Central America, India, Nepal and the Moluccan archipelago. Non-indigenous but still highly biodiversity-reliant communities in developed countries also figure prominently, including marine-dependent peoples in Brittany, France and Tasmania, Australia. Those who are adapting include not only local communities, but also researchers, governments and commercial and other organisations, and the interactions between these groups can generate feedbacks that are negative or positive for biodiversity and their associated social-ecological systems.

Four papers in this Special Issue focus on adaptation in coastal or marine environments. In Europe, Brattland et al. (2019) examine changes in sea temperatures, overfishing and marine invasions that have influenced multiple adaptation strategies of coastal Sami households, governments and researchers, which together led to a regime shift in the Porsanger Fjord's social-ecological system. Also dealing with coastal climate hazards, Garineaud (2019) addresses effects of violent storms on ocean kelp and coastal seaweed resources in coastal Brittany, France, and subsequent adaptations among kelp collectors and seaweed harvesters, including the adoption of new knowledge and practices. On the other side of the globe, Ellen (2019) examines how, in the Moluccas from 1600 onwards, resilience has been achieved on biologically poor and fragile islands through inter-island trade, and questions whether this historical resilience might be threatened by sea level rise. Pecl et al. (2019) investigate the autonomous adaptations of different marine stakeholders operating in the fast-warming waters off the east coast of Tasmania, Australia, where extensive climate-driven changes in biodiversity have been recorded. The analysis of Pecl and co-authors provides insights into factors that have constrained or facilitated the range of autonomous adaptation options documented and also highlights the potential countervailing interactions with planned governmental adaptations.

The other studies in the Special Issue focus on biodiversity change and adaptation in terrestrial systems managed by Indigenous People and other highly biodiversityreliant populations. In the Americas, de Echeverria and Thornton (2019) examine the responses of Pacific Northwest indigenous communities to changes in climate and biodiversity through the lens of several Cultural Keystone Indicator Species, including salmon, Sitka deer and wild berries used for subsistence and income. Rodríguez 
Valencia et al. (2019) seek to understand Costa Rican indigenous Bribri responses to invasive pathogens affecting their commercial crops, especially how social-ecological memory supported adaptation over time. In Asia, Thorn (2019) discusses climate, biological and economic change in the Terai region of Nepal that has resulted in a loss of natural biodiversity and agrobiodiversity, as well as increases in invasive pests and pathogens and many other stressors. She reports on multiple adaptations that occur on farms and in other resource areas, as well as in livelihoods, and on how new institutional forms of resource management have emerged. Thornton et al. (2019) examine human responses to biodiversity change provoked by an aggressive non-native invasive plant, Lantana camara L., in several agri-forest communities in the Male Mahadeshwara Hills of southern India. Howard (2019) also addresses invasive species but, in this case, the aim was to further develop the human adaptation to biodiversity change conceptual framework based on a literature metasynthesis of 55 invasive species case studies from across the globe, including both developing and developed regions, and agricultural, livestock or pastoralist, forest and wild resource systems.

\section{DRIVERS OF BIODIVERSITY CHANGE AND HUMAN ADAPTATION}

To date, most of the environmental change literature focuses on climate change as the primary driver of human adaptation $^{2}$ (Wise et al. 2014), where adaptation is by now considered to be an imperative. However, there are three reasons for focusing on biodiversity change both as a driver and as a component of human adaptation. First, as is argued in this volume, "The critical nexus for human adaptation...is not so much change in global temperature or precipitation regimes, but rather the consequent and relevant local changes in biodiversity that support the web of life" (Thornton et al. 2019). People who depend directly on natural resources for their livelihoods are, as much of the climate change literature attests (without acknowledging as much), responding to changes in cropping and livestock systems, forests and fisheries, that is, to biological change that is driven, at least in part, by climate change. Second, biodiversity change has many other drivers which, by

\footnotetext{
$\overline{2}$ The Human Adaptation to Biodiversity Change (HABC) Project sought to review literature on this topic; this review has been ongoing since 2011. The use of terms directly related with 'human adaptation' and 'biodiversity change' yields very few citations. The use of many terms associated with biodiversity change (e.g. 'biodiversity loss') also yields few citations. The vast majority of literature referring to 'adaptation' and biodiversity change terms refers to non-human species.
}

comparison, are as yet more important than climate change-including land-use change and habitat fragmentation, pollution, species invasions and over-exploitation (Ichii et al. 2019). Third, biodiversity change is occurring at an alarming rate across all of the earth's biospheres, in terrestrial, freshwater and oceanic regimes (MEA 2005; Ichii et al. 2019). This change takes many forms, from local species loss to global extinctions, changes in species abundances and distributions, in community composition and interactions, in phenology and length of growing and reproductive seasons and in pests and disease incidences affecting all organisms (Tylianakis et al. 2008; Scheffers et al. 2016; Sirami et al. 2017). It is affecting all aspects of human life and all dimensions of human well-being, and people must and will respond to these changes, and adapt (Howard 2009; Pecl et al. 2017). Human adaptation to biodiversity change, as Howard's (2019) review on adaptation to invasive species illustrates, in turn feeds back into these change processes and alters them (see also Ellis 2011; Bull and Maron 2016).

These points are well illustrated by the articles in this Special Issue. Changes in climate, weather and extreme events are a suite of related drivers of change in the phenology, abundance, distribution and behaviour of specific keystone species that are important to Indigenous People and that serve as indicators of environmental change in the Pacific Northwest. However, other drivers are also implicated in biodiversity change, including pollution, overharvesting and land-use change (de Echeverria and Thornton 2019). In Norway, changes in sea temperatures appear to be at least partly responsible for increases and decreases in major oceanic resources and fish stocks, which in turn amplified biodiversity change, such as a major seal invasion and overharvesting. The introduction of a non-native invasive species fishery, together with changes in fisheries governance that safeguards Indigenous small-scale fisheries, constitute a new phase of adaptation after a regime shift in the fjord ecosystem under scrutiny (Brattland et al. 2019). In Brittany, extreme weather events triggered major changes in kelp and seaweed resources, but the rapid adaptations that ensued were largely related to harvesting regimes, or the management of kelp and seaweed as resources (Garineaud 2019). In Costa Rica, the impacts of invasive pathogens forced responses that were also shaped by changing commercial opportunities for major crops, the knowledge and agrobiodiversity that Indigenous People held, as well as the knowledge and genetic diversity that outsiders shared (Rodríguez Valencia et al. 2019). In Nepal, rice farmers adapted to numerous climate change drivers that influenced changes in pest and disease incidence, phenology and length of growing seasons and water availability, but these were compounded by other changes in biodiversity related with pollution, overharvesting and 
the introduction of hybrid varieties, some of which were triggered by government intervention and some by adaptation (Thorn 2019). In India, the primary recent driver of biodiversity change affecting forest resources and agriculture, as well as well as the people who manage and depend upon these, was the invasion of the flowering plant Lantana camara (Thornton et al. 2019), one of the world's ' 100 worst invasive species. ${ }^{3}$ Invasive species are a major driver of biodiversity change globally (Mazor et al. 2018), and Howard (2019) identified 89 different, often interacting environmental, economic, socio-political and technological drivers of both invasions and adaptation across 55 case studies.

\section{WHY, AND WHAT IS, AUTOCHTHONOUS ADAPTATION?}

The HABC project focused on adaptation to biodiversity change at local levels, or 'from below'. It introduced the concept of 'autochthonous adaptation,' contrasting it with concepts found in the mainstream environmental change literature. In 2007, for example, the Intergovernmental Panel on Climate Change (IPCC) presented two adaptation categories-'autonomous' and 'planned'-and defined autonomous adaptation as "adaptation that does not constitute a conscious response to climatic stimuli but is triggered by ecological changes in natural systems and by market or welfare changes in human systems." Planned adaptation is "the result of a deliberate policy decision, based on an awareness that conditions have changed or are about to change and that action is required to return to, maintain, or achieve a desired state" (IPCC 2007). ${ }^{4}$ In 2014, the IPCC showed that autonomous adaptation was used to refer to actions associated with non-climate change drivers (e.g. diversification in response to economic change) that inadvertently "can increase long-term ability

\footnotetext{
3 http://www.iucngisd.org/gisd/100_worst.php.

4 The definition of autonomous adaptation was changed in the IPCC 2014 report, which reads: "Adaptation in response to experienced climate and its effects, without planning explicitly or consciously focused on addressing climate change" (IPCC 2014). Autonomous adaptation is also used in relation with ecosystems, "including their human components, without external intervention, in response to a changing environment-also called 'spontaneous adaptation'. In the context of human systems it is sometimes called 'coping capacity'. Autonomous adaptations are incremental changes in the existing system including through the ongoing implementation of extant knowledge and technology in response to the changes in climate experienced. They include coping responses and are reactive in nature" (Porter et al. 2014, p. 513). The IPCC also uses concepts related to adaptation types but refers to these as 'strategies', including diversification, migration, storage of food, communal pooling, market responses; and saving, credit societies, and systems of mutual support (Olsson et al. 2014, p. 815).
}

to cope with a changing climate"- "the use of the term in the literature, including the IPCC reports, has been inconsistent" (Noble et al. 2014, p. 838). Other inconsistencies include whether autonomous adaptation refers to actions that are purposeful or unintentional, or are reactive or proactive. There is also the assertion that it is independent of outside influence: "purposeful adaptation actions carried out by agents without external inputs such as policies, information, or resources" (Noble et al. 2014, p. 838).

Here, the concept of autochthonous is defined as, literally, 'native to the soil,' 'native to the place where found' and, in biology, 'native to or produced within a system.' Autochthonous adaptation has four fundamental dimensions: (1) it is deliberate; (2) it refers to individuals and small groups of individuals; (3) it is specific to the locality-specific environmental, social and cultural conditions that prevail in specific places where people live and act and (4) it occurs within a local system, which is affected by multi-scalar drivers and feedbacks-thus, it is not independent of 'external inputs' (Thornton et al. 2019). The latter is indirectly acknowledged in the IPCC when it states that, "there is now high confidence that public decision making for adaptation can be strengthened by understanding the decision making of rural people in context, and in particular considering examples of autonomous adaptation and the interplay between informal and formal institutions" (own emphasis; Dasgupta et al. 2014, p. 638). Howard thus defines autochthonous adaptation as "deliberate adaptation actions undertaken by individuals or small social groups that are specific to and occur within a local system, where human populations are ultimately affected" (2019).

The concept of autochthonous adaptation is derived from what anthropologists refer to as cultural adaptation. While cultural adaptation refers to the four types of adaptation that all organisms display (phylogenetic, physiological, learning and cultural), the dominant form of cultural adaptation today 'involves modification through a combination of learning and use of socially transmitted information or practices,' and occurs as populations "deliberately modify behaviour on the basis of their perception of the world: to maintain certain conditions, cope with hazards, or adjust to new conditions" (Ellen 2018, p. 1). Adaptation has occurred throughout human history, whether in the presence or absence of states, religious institutions and other supra-collectivities that manipulate local human populations in their own interests (Ellen 2018). Thus, current definitions of 'autonomous' and 'planned' adaptation can be contrasted with the four 'autochthonous' adaptation dimensions listed above, and may be more useful for guiding research and policy (Grüneis et al. 2016; Howard 2019; Pecl et al. 2019; Thornton et al. 2019). 'Planned' adaptation can manipulate but not determine 
what individuals or small groups of individuals actually do. Autochthonous adaptation is in part influenced "by market or welfare changes in [local] human systems" and "ecological changes in natural systems," but these are always mediated by changes affecting the modes of subsistence that people directly manage for their living, cultural wellbeing and survival, as the discussion of drivers above demonstrates.

As reflected in this Special Issue, many scientists who research adaptation processes and outcomes use the term 'autonomous adaptation,' deploying their own sophisticated concepts and definitions that do not necessarily reflect the limitations of the IPCC definitions (Pecl et al. 2019). To achieve greater clarity and conceptual consistency, the $\mathrm{HABC}$ project proposed and developed the autochthonous adaptation concept to capture the fact that such adaptation occurs everywhere, in the presence or absence of planned adaptation, either in synergy or conflict. As well, across much of the globe, as our current environmental crises so clearly attest, planned adaptation to environmental change is either absent, only weakly implemented or, in some cases, even backfires. Autochthonous adaptation thus always plays not only a major, but very likely a defining role in both our community and common futures. Adaptation cannot simply be planned 'top down,' as it continuously emerges from the micro- and meso-organisational levels of human societies as well. In other words, individuals and households must adapt, as must communities and states, to sustain themselves in a changing environment characterised by multilevel interactions and impacts of both environmental change and adaptation (Howard 2019). 'Managing' adaptation in a globalised world thus necessarily involves connecting these levels and their constituent actors, pathways and institutional nodes (Pecl et al. 2019).

Thus, in her case study on adaptation to biodiversity change in the Terai region of Nepal, Thorn notes that people "often adapt in ways that are unaided by external agencies, nor necessarily reflected in formal policies...The existing literature has primarily focused on adaptation strategies that can be implemented on a large-scale in developed countries" (Thorn 2019). When addressing adaptation to Lantana camara invasion in southern India, Thornton et al. similarly argue that "autochthonous adaptation processes either go unrecognized or are actively undermined as a consequence of colonialism, development, state-formation, and globalization" (Thornton et al. 2019).

In several of the cases, in addition to autochthonous adaptation, numerous other actors or agents were directly involved in adaptations of their own that intersected with local people's adaptations. In some cases, outside agents supported autochthonous adaptations, leading to different partial forms of 'co-management' while, in other cases, these adaptations worked at cross-purposes. In Costa Rica, the Bribri were supported by external agents that provided pathogen-resistant varieties that people subsequently adopted; management of pathogens was achieved through a combination of local and new knowledge introduced via the Bribri's social networks (Rodríguez Valencia et al. 2019). In Brittany, new forms of co-management emerged between harvesters, scientists and fisheries authorities; when new regulations around seaweed harvesting were introduced that were intended to promote seaweed regeneration, locals challenged these regulations as scientifically unfounded. Researchers then carried out experiments to determine whether these regulations were merited. "Knowledge has evolved rapidly through interaction with the natural environment but also through exchanges with scientists. The reinforcement of these exchanges appears to be central to foster resilience throughout the human-marine system" (Garineaud 2019).

Several cases address "how existing top-down governance, or 'planned' adaptation measures, may effectively limit or subvert local autochthonous adaptation through policies of encroachment, appropriation, development, and conservation" (Thornton et al. 2019; see also Howard 2019). Policy mismatches are also very much in evidence, as governments or regulators seek to adapt in ways that constrain or undermine autochthonous adaptation. In Nepal, the government Land Act of 1964 changed land use and population dynamics, and increased agricultural intensification and deforestation, which also depleted aquifers, leading to major declines in biodiversity. Local people adapted in part by developing local institutions for managing forests, water and agrobiodiversity, and to prevent wildlife conflicts. National policies have been developed to address ongoing problems, but to date with only weak implementation (Thorn 2019). In the Pacific Northwest, regulations on resource harvesting were too rigid to take local knowledge, needs and climatic variation in biological resources into account, constraining people's capacity to adapt. However, when communities and regulators worked together, this resulted in a ban on trawling and thus overfishing, and fine-tuning of regulations to enhance and protect salmon stocks (de Echeverria and Thornton 2019). The most striking case of multiple mismatches in biodiversity change adaptation efforts is evident in Brattland et al.'s (2019) case, where fishing authorities' impositions of a vessel quota system seriously constrained Sami fisherfolk's adaptive capacity. The government's later promotion of invasive king crab fisheries both improved the Sami's ability to regain their flexible livelihood system and excluded some groups of small-scale fishers from participation. Scientists were critiqued for failing to consider local knowledge and later worked to address this; new research efforts on fjord ecosystems were 
an "action in response to change" as municipal and regional governments reached out to researchers to "understand and mitigate effects of climate and biodiversity change" (Brattland et al. 2019).

\section{CONCEPTUAL FRAMEWORKS AND TOOLS}

Researchers formulated numerous innovative approaches and conceptual tools to address this novel theme, which are the most valuable contributions that this volume makes to environmental change research. Several scientists adopted a social-ecological systems approach and applied, elaborated upon or revised concepts from the adaptation to environmental change literature. 'Fitting' these to human adaptation to biodiversity change has led to an evolution in these concepts, as they were adapted and applied to different processes and contexts-where biodiversity change drivers are highly significant, where people are responding principally to changes in species, species communities and related ecosystem processes, and where adaptation entails changes in the management of biodiversity and related resource use regimes.

Many articles are based on social-ecological systems theory, including the axiom that humans and ecosystems are intertwined. Fundamental concepts include socialecological system drivers and feedbacks, resilience, regime shifts and transformation (see Howard 2019). Rodríguez Valencia et al. (2019) used the concept of social-ecological memory from resilience thinking to examine the ways that people draw upon both biological materials and social memory to reorganise following disturbance, in their case, in response to invasive pathogens that, over time, repeatedly threatened crops. Bribri adaptation to invasive pathogens could be understood as "a dynamic process through which biological resources, and people's traditional knowledge, practices, values, and skills, and when needed their networks (to access reservoirs of outside knowledge), are creatively used to respond to an everchanging environment" (Rodríguez Valencia et al. 2019).

Brattland et al. (2019) analyse the interactions between local adaptation and ecosystem processes to develop and apply the concept of 'social-ecological timelines.' These are based on longer timeframes and include major events, tipping points and regime shifts. Timelines provide a method for integrating local and scientific knowledge and for "understanding, documenting and researching human adaptation to biodiversity change" (Brattland et al. 2019). Their timeline reveals two distinct phases in a fjord socialecological system, separated by an invasion of seals, the collapse of local fisheries and the introduction of a government fishing quota system, "from which the fjord never recovered," and a subsequent phase, surprisingly based on the invasion of non-native king crabs, which largely allowed the Sami to recover their livelihood flexibility, a hallmark of their historical adaptation pathways.

Thornton et al. (2019) based their research on Lantana camara on the HABC project framework, but go beyond this to critically examine current framings of adaptation processes and formulate a series of questions that might be posed to understand human adaptation to biodiversity change processes more generally. They further develop the 'adaptation pathways' approach, advancing a new 'adaptation processes-to-pathways' framework. Like Brattland et al. (2019), they recognise the need to understand how adaptation pathways have evolved over longer timescales ('historical-ecological backcasting'); without this, it wouldn't be possible to assess whether Lantana invasion can be reversed, or instead is a biological force that will continue to drive adaptation. They apply an adaptation typology developed by Thornton and Manasfi (2010), finding that "adaptation processes are developing to make Lantana less disruptive and more useable-from avoidance through mobility strategies to utilizing the plant for economic diversification" (Thornton et al. 2019).

Howard (2019) develops a conceptual framework for understanding human adaptation to invasive species that was also based initially on the HABC framework. She allowed the human adaptation to invasive species framework to emerge from a literature metasynthesis of case studies, interpreting this in a social-ecological systems framing, and adopting and modifying the adaptation pathways and types approach advanced by Thornton et al. (2019). She finds that change drivers include biological invasions and other drivers that affect both invasion and adaptation. Invasive impacts on human well-being are the primary adaptation drivers, as people seek to change these impacts. Her concept of adaptation 'spheres' refers to invasive control and management, resource use and management systems, households and micro- and meso-scales, including cross-scale interactions. A second set of framework concepts refers to adaptation pathways, types, feedbacks and outcomes in terms of social-ecological system instability, resilience, regime shift and transformation. Howard partly revises and expands upon the adaptation typology in Thornton and Manasfi (2010) to consider types of adaptation that are specifically associated with biodiversity change, such as ecological diversification, resource tracking, disintensification and shifts in species.

Ellen (2019) presents a wider-scale and longer-term analysis of resilience based on historical ecology to examine environmentally vulnerable volcanic islands and low-lying coral reefs, some only 1.5 metres above sea level, and all of which represent 'biodiversity cold spots' with sparse vegetation and low biological diversity. $\mathrm{He}$ shows how inter-island trade allows people to overcome 
numerous shocks, increase population numbers, develop infrastructure, alter island topography and change their relations with sparse vegetation. In a broader conceptualisation, inter-island trade could be considered as an additional type of adaptation to environmental change-the establishment of 'human biological corridors' (Howard 2009)—where biological resources from one area are exchanged for those in other areas, thus supplementing missing or scarce resources across ecological gradients or, in the case of the Moluccas, seven different biomes.

In addition to advancing social-ecological systems and adaptation concepts, several researchers provide new ways to address the biodiversity change-human adaptation nexus. For many, a focus on local knowledge is key (e.g. Pecl et al. 2019), as it may be most important asset that people deploy when adapting to biodiversity change, as well as the most important source of information about local environmental change and autochthonous adaptation. However, local knowledge is recognised as complex and dynamic, and rarely as exclusively 'traditional'-concepts such as 'composite' or 'hybrid' knowledge, 'knowledge sharing' and 'knowledge networks' are used to highlight the interplay and fusions between local, scientific and technical knowledge (de Echeverria and Thornton 2019; Garineaud 2019; Rodríguez Valencia et al. 2019).

Authors de Echeverria and Thornton (2019) merged concepts of ecological and cultural keystone species to examine 'Cultural Keystone Indicator Species'- species of critical "cultural importance and perceptual salience in relation to environmental change." By identifying and examining Cultural Keystone Indicator Species, they were able to reveal relationships between traditional ecological knowledge, cultural ecosystem services and impacts and adaptation to climate and other biodiversity change drivers. They argue that "Local knowledge and practices remain the foundation for any response, and are often the only interventions to reduce risks" (de Echeverria and Thornton 2019). In Brattland et al. (2019), 'social-ecological timelines' merge local and scientific knowledge when neither provides sufficient basis for understanding how socialecological system change and adaptation are intertwined. Rodríguez Valencia et al. (2019) use 'social-ecological memory' to provide key insights into how the mobilisation of knowledge and biological resources over time, space and through social networks allows people to adapt to new biosecurity threats. Garineaud (2019) uses an ethnoecological approach to reveal how kelp harvesters' unique classification system of underwater kelp topography, used both to locate kelp resources and demarcate gathering rights, changed rapidly in response to shifts in kelp resources that resulted from extreme weather events.

\section{DOES IT MATTER WHO IS ADAPTING?}

Many of the case studies in this Special Issue focus on Indigenous Peoples whose adaptation pathways are strongly conditioned not only by their strong reliance on local biological resources and reservoirs of local ecological knowledge, but as well by political marginalisation and external socio-political and economic drivers. As Thornton et al. note, "Indigenous Peoples, ethnic minorities, and subsistence populations often have little choice but to 'adapt' to the dominant socio-political system and its objectives for growth and "progress" (Thornton et al. 2019). Thorn (2019) argues further that "rural farming populations are particularly unique, in that they have stewarded and directly depended on some of the Earth's most unique biodiversity for thousands of years. Their vulnerability differs to other systems where services are more likely to be substitutable" (Thorn 2019). This holds irrespective of whether Indigenous Peoples dwell in highly industrialised Western societies or in poorer developing regions. In all of the cases presented here, Indigenous Peoples are embedded in market chains and are subject to overarching political forces, drivers and regulations.

When examining 55 case studies on adaptation to invasive species, Howard (2019) finds that, "in cases where local resource management systems have evolved over fairly long time periods within vacillating ecological environments, and local ecological knowledge has evolved to manage biological change, people often prevented invasion, 'restored' invaded environments, or generated far greater benefits by altering resource systems to create greater biodiversity, use and exchange value, and human well-being." This accords with Nunn and Kumar's (2019) findings on adaptation to environmental change in Fiji, which reverse most assumptions found in the literature about the adaptive capacity of the 'poor' who are highly dependent upon biological diversity (e.g. Campbell et al. 2009): the more peripheral the community, the greater its adaptive capacity. Howard (2019), however, goes on to argue:

In some cases, even in the presence of these conditions, socio-economic, economic and technological drivers both overwhelmed and undermined local adaptive capacity, generating vicious invasion processes, major positive feedbacks and regime shift. Thus, human capacity to mitigate harms and derive benefits from invasions is, at the end of the day, a dependent variable. Misguided policies, political and economic marginalisation, loss of ecological knowledge and increasing social differentiation and conflict generate poverty, undermine local governance and 
adaptive capacity and ensure that the least powerful bear the brunt of 'vicious invasions'.

Indigenous Peoples differ in their ability to influence the political and regulatory regimes that often constrain or undermine their adaptive capacity. Some recur to self-organisation or learn to use external support mechanisms (e.g. Garineaud 2019; Rodríguez Valencia et al. 2019; Thorn 2019); some use their agency to insist on change, as was the case with the Coastal Sami Uprising in Finnmark, an indigenous protest against cod overfishing by vessels that used more effective technology (Brattland et al. 2019). The government responded to this uprising by banning fishing with Danish seine (an active gear type) in the cod spawning season. However, this response was not enough to prevent over-exploitation on some spawning grounds. Howard (2019) shows that species invasions and adaptation can generate conflict between Indigenous Peoples and governments, as well as between Indigenous Peoples, and is more common than what is reported in the invasive science literature.

Among the non-indigenous populations treated in the case studies, Garineaud (2019) focuses on French coastal seaweed and ocean kelp collectors. Seaweed collectors are a larger and more heterogeneous group, in their majority women who traditionally did not use boats. "Half of the seaweed gatherers learned from their families, while the other half learned over the years from popular or scientific literature" (Garineaud 2019); nevertheless, coastal seaweed harvesters are more aware of subtle environmental changes compared with ocean-going kelp harvesters. Many kelp harvesters are from families that have engaged in this activity over generations; adaptation requires that they become more mobile and flexible, which is more difficult for those who have a longer historical relation with specific harvesting locations. In part due to the commercial interests involved, these populations have developed important relations with local management authorities and researchers.

The case study presented by Pecl et al. (2019) of marine stakeholders in Tasmania includes a broad spectrum of people involved in recreational, subsistence or commercial use and management of marine resources, each of which adopt different forms of adaptation based on different knowledge systems, but nearly all of whom adapt practices and behaviour that are directly related to building resilience. All of these cases show that adaptation options and pathways are strongly associated with peoples' positions in social, economic and political hierarchies, and their ability to leverage resources and political influence to alter either biodiversity change drivers or their room for manoeuvre.

\section{QUESTIONS FOR FUTURE RESEARCH AND POLICY}

The HABC project initially formulated a series of questions that were not intended to guide research or policy, but instead to frame the theme in broad terms. As is the case with research more generally, questions or hypotheses are formulated and explored through research, resulting in new sets of questions or hypotheses. Those questions and the general questions that guided the case study research and metasynthesis presented in this Special Issue are listed in Table 1. They were found to cluster around sub-themes: historical antecedents to contemporary adaptation processes, adaptation actions and actors, factors that facilitate or constrain adaptation, multi-scalar influences and emergent properties of adaptation, adaptation outcomes, relations between autochthonous adaptation and policies or planned interventions, and future scenarios. These questions emerge when considering specific adaptation drivers, contexts and agents, and certainly future research will serve to clarify and formulate new questions, as well as approaches, methods and tools, that add to, refine and reformulate these queries. We believe that, with the publication of this volume, we have gone some way towards conceptualising and illustrating the relevance of human adaptation to biodiversity change as a new terrain for science and policy endeavours. 
Table 1 General questions raised about human adaptation to biodiversity change in the ESPA HABC project and in the Special Issue

\begin{tabular}{lll}
\hline Dimensions & Source & Question \\
\hline Antecedents & Thornton et al. $\begin{array}{c}\text { How have adaptation processes developed in relation to ecosystem services and human well-being in } \\
\text { a historical-ecological context? }\end{array}$ \\
Adaptation actions & $\begin{array}{c}\text { ESPA HABC } \\
\text { Project }\end{array}$ & $\begin{array}{c}\text { How quickly can human populations respond to changes in species composition and richness, } \\
\text { ecosystem services and to changes in states or regimes, 'reengineering' social-ecological systems } \\
\text { in ways that are desirable in terms of human welfare, biodiversity and ecosystem services? }\end{array}$
\end{tabular}

Brattland et al. How should rural and indigenous communities take action to maintain their traditional livelihood adaptations and social-ecological resilience in the face of climate and biodiversity change?

Howard How do humans adapt to invasive species?

ESPA HABC Are changes in biodiversity so rapid and significant that they overwhelm human capacity to respond Project or are humans, especially those in highly biodiversity dependent societies, highly capable innovators that can provide lessons for humanity at large?

Pecl et al. What forms of adaptation actions are being undertaken by users (i.e. non-government sector actors) in response to high levels of ecological change in marine systems?

Actors

Facilitators scale interventions

Future scenarios

Outcomes
Emergent properties,

Policies and planned

Pecl et al.

ESPA HABC

Project $\begin{array}{cc}\text { ESPA HABC } & \text { How are cultural values, economic systems, institutional arrangements, knowledge and social and } \\ \text { Project } & \text { physical mobility linked or not to human capacity to respond or adapt to rapid biological and }\end{array}$

Pecl et al.

Howard

Pecl et al.

Pecl et al.

ESPA HABC

Project

Pecl et al.

ESPA HABC

Project

ESPA HABC

Project

Howard

Pecl et al. ecological change?

What key assets do users have to enable adaptation actions?

How do social relations at micro- and meso- scales affect adaptation pathways?

What level of access do users have to formal power over marine resources?

How dependent is the adaptation action on government cooperation?

What are the intended and unintended effects, or emergent properties, of human responses to biodiversity and related ecosystem change and tipping points?

What is the geographic scale of adaptation behaviours or actions and expected outcomes?

Are there predictable trajectories of response given particular patterns of change, environments and social-economic systems, and are there variables and processes that cut across such systems?

Are there 'black box' variables that facilitate or impede adaptation at different scales and can they be illuminated by science?

How do adaptation pathways affect social-ecological relations and outcomes at micro- and mesoscales?

What are the expected outcomes of the adaptation behaviour for different levels of ecological vulnerability of the marine socio-ecological system and socio-economic vulnerability of affected marine users? What type of benefit is generated?

Thornton et al. What costs/benefits result for ecosystem services (ES) and well-being from pursuits of specific pathways that support some adaptation processes and not others? Why?

Thornton et al. How can interventions support autochthonous adaptation strategies that already contribute to ecosystem health and human well-being?

Thornton et al. What is needed to ensure continued assessment and support for autochthonous adaptation responses to environmental change and its impacts in the future?

Brattland et al. What adaptation strategies should be facilitated in order to maintain the resilience of coastal socialecological systems?

Howard Under which circumstances should policies and management plans seriously address human adaptation to invasive species as a response option?

Pecl et al. How may the observed adaptation behaviours potentially interact with planned government efforts and what are the implications for further adaptation planning?

Thornton et al. How might adaptation processes intersect and play out under future scenarios of social-environmental change and response at different scales? 
Dedication

We dedicate this Special Issue to Claudia Comberti (1985-2017), who was to contribute an article to this publication when she was tragically killed in a road accident in May, 2017, before she could finish it. At the time, Claudia was nearing completion of her DPhil thesis at Oxford's School of Geography and the Environment. She had already co-authored several publications based on her research on climate change adaptation among Amazonian Indigenous communities. Claudia was especially interested in the role of human-ecosystem interactions and biocultural diversity in supporting resilience and positive responses to environmental change. She conducted extensive anthropological and socialecological research with Indigenous communities of the Bolivian and Peruvian Amazon, including Brazil nut harvesting communities of the Tacana II group and agroforestry communities in the Llanos de Moxos region of Bolivia (Fig. 1). She was also a passionate campaigner for social and environmental justice in the region as well as in her home country, the UK. Tributes to Claudia and more information on her research can be found at: https://www. geog.ox.ac.uk/graduate/research/ccomberti.html and http://www. claudiacomberti.com/advocacy-continuing-the-fight/.

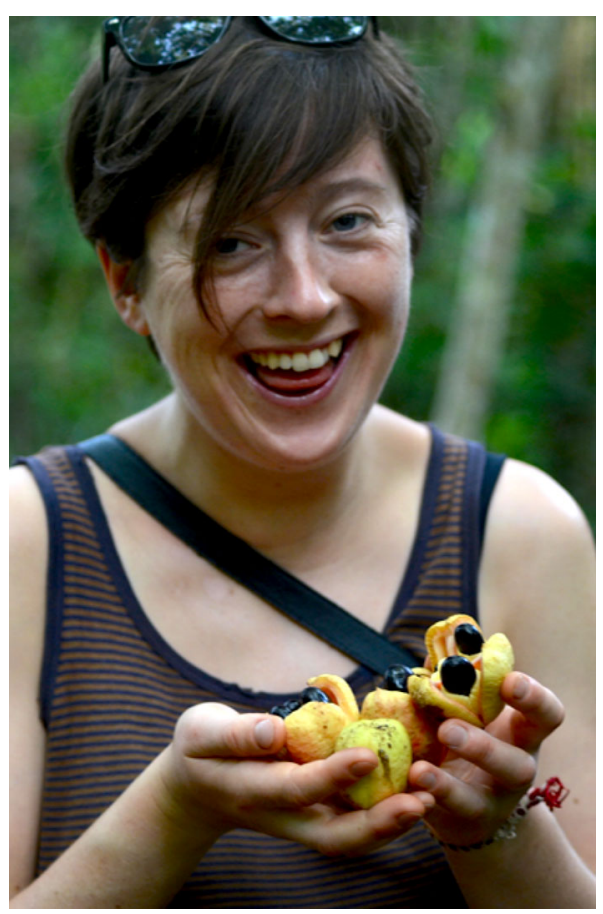

Fig. 1 Claudia Comberti conducted extensive anthropological and social-ecological research with Indigenous communities of the Bolivian and Peruvian Amazon. Photo by Jessica Thorn
Acknowledgements Funding for the Human Adaptation to Biodiversity Change (HABC) project was provided by the Ecosystem Services and Poverty Alleviation programme of the UK Government. ESPA was "a nine year global interdisciplinary research programme that aimed to give decision-makers and natural resource users the evidence they need to address the challenges of sustainable ecosystem management and poverty reduction." http://www.espa.ac.uk/about/ espa. Gretta Pecl was funded by an Australian Research Council Future Fellowship. Special thanks are extended to Ambio's Editor, who encouraged and stewarded this Special Issue, and to the Special Issue Co-editors, Rajindra Puri and Thomas Thornton, as well as to all of the contributors and reviewers.

\section{REFERENCES}

Bebber, D.P., M.A. Ramotowski, and S.J. Gurr. 2013. Crop pests and pathogens move polewards in a warming world. Nature Climate Change 3: 985-988. https://doi.org/10.1038/nclimate1990.

Bell, J.D., A. Ganachaud, P.C. Gehrke, S.P. Griffiths, A.J. Hobday, O. Hoegh-Guldberg, J.E. Johnson, R. Le Borgne, et al. 2013. Mixed responses of tropical Pacific fisheries and aquaculture to climate change. Nature Climate Change 3: 591-599. https://doi.org/10. 1038/nclimate1838.

Boivin, N.L., M.A. Zeder, D.Q. Fuller, A. Crowther, G. Larson, J.M. Erlandson, T. Denhami, and M.D. Petraglia. 2016. Ecological consequences of human niche construction: Examining longterm anthropogenic shaping of global species distributions. PNAS 113: 6388-6396. https://doi.org/10.1073/pnas. 1525200113
Brattland, C., E. Eythórsson, J. Weines, and K. Sunnanå. 2019. Social-ecological timelines to explore human adaptation to coastal change. In Human adaptation to biodiversity change in the anthropocene, eds. P.L. Howard, G.T. Pecl, R.K. Puri, and T. F. Thornton, Ambio vol. 48, Special Issue. https://doi.org/10. 1007/s13280-018-1129-5.

Bull, J.W., and M. Maron. 2016. How humans drive speciation as well as extinction. Proceedings of the Royal Society B: Biological Sciences. https://doi.org/10.1098/rspb.2016.0600.

Campbell, A., V. Kapos, A. Chenery, S.L. Kahn, M. Rashid, J. Scharlemann, and B. Dickson. 2009. The linkages between biodiversity and climate change mitigation: A review of the recent scientific literature. Oxford: United Nations Environment Programme World Conservation Monitoring Centre (United Nations Environment Programme-WCMC).

Campbell, B.M., S.J. Vermuelen, P.K. Aggarwal, C. Corner-Dolloff, E. Girvetz, A.M. Loboguerrero, J. Ramirez-Villegas, R. Rosenstock, et al. 2016. Reducing risks to food security from climate change. Global Food Security 11: 34-43. https://doi.org/10. 1016/j.gfs.2016.06.002.

Chaplin-Kramer, R., R.P. Sharp, C. Weil, E.M. Bennett, and U. Pascual. 2019. Global modeling of nature's contributions to people. Science 366: 255-258. https://doi.org/10.1126/science. aaw3372.

Dasgupta, P., J.F. Morton, D. Dodman, B. Karapinar, F. Meza, M.G. Rivera-Ferre, A. Foure Sarr, and K. E. Vincent. 2014. Rural areas. In Climate change 2014: Impacts, adaptation and vulnerability. Part A: Global and sectoral aspects. Contribution of Working Group II to the Fifth Assessment Report of the 
Intergovernmental Panel on Climate Change, 613-657. Cambridge: Cambridge University Press.

Díaz, S., S. Demissew, J. Carabias, C. Joly, M. Lonsdale, N. Ash, A. Larigauderie, J.R. Adhikari, et al. 2015. The IPBES conceptual framework-connecting nature and people. Current Opinion in Environmental Sustainability 14: 1-16. https://doi.org/10.1016/j. cosust.2014.11.002.

Ding, H., and P.A. Nunes. 2014. Modeling the links between biodiversity, ecosystem services and human wellbeing in the context of climate change: Results from an econometric analysis of the European forest ecosystems. Ecological Economics 97: 60-73. https://doi.org/10.1016/j.ecolecon.2013.11.004.

de Echeverria, V.R.W., and T.F. Thornton. 2019. Using traditional ecological knowledge to understand and adapt to climate and biodiversity change on the Pacific coast of North America. In Human adaptation to biodiversity change in the anthropocene, eds. P.L. Howard, G.T. Pecl, R.K. Puri, and T. F. Thornton, Ambio vol. 48, Special Issue. https://doi.org/10.1007/s13280019-01218-6.

Ellen, R. 2018. Cultural adaptation. In The international encyclopedia of anthropology, ed. H. Callan. New York: Wiley. https://doi. org/10.1002/9781118924396.wbiea1914.

Ellen, R. 2019. The impacts of local networks on subsistence resilience and biodiversity in a low-lying Moluccan reef system between 1600 and the present. In Human adaptation to biodiversity change in the anthropocene, eds. P.L. Howard, G.T. Pecl, R.K. Puri, and T. F. Thornton, Ambio vol. 48, Special Issue. https://doi.org/10.1007/s13280-018-1091-2.

Ellis, E.C. 2011. Anthropogenic transformation of the terrestrial biosphere. Philosophical Transactions of the Royal Society of London A: Mathematical, Physical and Engineering Sciences 369: 1010-1035. https://doi.org/10.1098/rsta.2010.0331.

Gaertner, M., R. Biggs, M. Te Beest, C. Hui, J. Molofsky, and D.M. Richardson. 2014. Invasive plants as drivers of regime shifts: Identifying high-priority invaders that alter feedback relationships. Diversity and Distributions 20: 733-744. https://doi.org/ 10.1111/ddi.12182.

Garineaud, C. 2019. Evolving adaptive capacity of seaweed harvesters in Brittany. In Human adaptation to biodiversity change in the anthropocene, eds. P.L. Howard, G.T. Pecl, R.K. Puri, and T. F. Thornton, Ambio vol. 48, Special Issue. https://doi.org/10. 1007/s13280-018-1119-7.

Grüneis, H., M. Penker, and K.-M. Höferl. 2016. The full spectrum of climate change adaptation: Testing an analytical framework in Tyrolean mountain agriculture (Austria). Springerplus 5: 1848. https://doi.org/10.1186/s40064-016-3542-1.

Hanewinkel, M., D.A. Cullmann, M.-J. Schelhaas, G.-J. Nabuurs, and N.E. Zimmermann. 2013. Climate change may cause severe loss in the economic value of European forest land. Nature Climate Change 3: 203-207. https://doi.org/10.1038/nclimate1687.

Howard, P.L. 2009. Human adaptation to biodiversity change: Facing the challenges of global governance without science? Paper presented at the Amsterdam Conference on the Human Dimensions of Global Environmental Change, "Earth Systems Governance," 2-4 December 2009, Amsterdam, The Netherlands. Accessed September 9, 2019, from https://www.academia.edu/ 198178/Human_Adaptation_to_Biodiversity_Change__ Facing_the_Challenges_of Global_Governance_without_Science.

Howard, P.L. 2013. Human resilience in the face of biodiversity tipping points at local and regional scales. In Addressing tipping points for a precarious future, ed. T. O'Riordan and T. Lenton, 104-126. Oxford: British Academy and Oxford University Press.

Howard, P.L. 2019. Human adaptation to invasive species: A conceptual framework based on a case study metasynthesis. In
Human adaptation to biodiversity change in the anthropocene, eds. P.L. Howard, G.T. Pecl, R.K. Puri, and T. F. Thornton, Ambio vol. 48, Special Issue. https://doi.org/10.1007/s13280019-01297-5.

Intergovernmental Panel on Climate Change (IPCC). 2007. Climate change 2007: Contribution of Working Group II to the Fourth Assessment Report of the Intergovernmental Panel on Climate Change: Impacts, adaptation and vulnerability. Appendix I. Glossary, ed. M.L. Parry, O.F. Canziani, J.P. Palutikof, P.J. van der Linden, and C.E. Hanson. Cambridge: Cambridge University Press.

Intergovernmental Panel on Climate Change (IPCC). 2014. Annex II: Glossary. Climate change 2014: Impacts, adaptation and vulnerability. Part A: Global and sectoral aspects. Contribution of Working Group II to the Fifth Assessment Report of the Intergovernmental Panel on Climate Change. Cambridge: Cambridge University Press.

Ichii, K., Z. Molnár, D. Obura, A. Purvis, and K. Willis. 2019. Status and trends-nature. IPBES global assessment on biodiversity and ecosystem services. Unedited draft. Intergovernmental Science-Policy Platform on Biodiversity and Ecosystem Services. Accessed October 14, 2019, from https://www.ipbes.net/ global-assessment-report-biodiversity-ecosystem-services.

Leadley, P., V. Proença, J. Fernández-Manjarrés, H.M. Pereira, R. Alkemade, R. Biggs, E. Bruley, W. Cheung, et al. 2014. Interacting regional-scale regime shifts for biodiversity and ecosystem services. BioScience 64: 665-679. https://doi.org/10. 1093/biosci/biu093.

Manners, R., and J. van Etten. 2018. Are agricultural researchers working on the right crops to enable food and nutrition security under future climates? Global Environmental Change 53: 182-194. https://doi.org/10.1016/j.gloenvcha.2018.09.010.

Mazor, T., C. Doropoulos, F. Schwarzmueller, D.W. Gladish, N. Kumaran, K. Merkel, M.-D. Marco, and V. Gagic. 2018. Global mismatch of policy and research on drivers of biodiversity loss. Nature Ecology \& Evolution 2: 1071-1074. https://doi.org/10. 1038/s41559-018-0563-x.

Millennium Ecosystem Assessment (MEA). 2005. Ecosystems and Human Well Being Synthesis. Washington, DC: Island Press.

Naeem, S., R. Chazdon, J.E. Duffy, C. Prager, and B. Worm. 2016. Biodiversity and human well-being: An essential link for sustainable development. Proceedings of the Royal Society B: Biological Sciences. https://doi.org/10.1098/rspb.2016.2091.

Noble, I.R., S. Hug, Y.A. Anokhin, J. Carmin, D. Goudou, F.P. Lansigan, B. Osman-Elash, and A. Villamizar. 2014. Adaptation needs and options. In Climate change 2014: Impacts, adaptation and vulnerability. Part A: Global and sectoral aspects. Contribution of Working Group II to the Fifth Assessment Report of the Intergovernmental Panel on Climate Change, 833-868. Cambridge: Cambridge University Press.

Nunn, P., and R. Kumar. 2019. Measuring peripherality as a proxy for autonomous community coping capacity: a case study from Bua Province, Fiji Islands, for improving climate change adaptation. Social Sciences 8: 225. https://doi.org/10.3390/socsci8080225.

Olsson, L., M. Opondo, P. Tschakert, A. Agrawal, S.H. Eriksen, S. Ma, L.N. Perch, and S.A. Zakieldeen. 2014. Livelihoods and poverty. In Climate change 2014: Impacts, adaptation and vulnerability. Part A: Global and sectoral aspects. Contribution of Working Group II to the Fifth Assessment Report of the Intergovernmental Panel on Climate Change, 793-832. Cambridge: Cambridge University Press.

Pascual, U., P. Balvanera, S. Díaz, G. Pataki, E. Roth, M. Stenseke, R.T. Watson, E. Başak Dessane, et al. 2017. Valuing nature's contributions to people: The IPBES approach. Current Opinion 
in Environmental Sustainability 26-27: 7-16. https://doi.org/10. 1016/j.cosust.2016.12.006.

Pecl, G.T., M.B. Araújo, J.D. Bell, J. Blanchard, T.C. Bonebrake, I.C. Chen, T.D. Clark, R.K. Colwell, et al. 2017. Biodiversity redistribution under climate change: Impacts on ecosystems and human well-being. Science. https://doi.org/10.1126/science. aai9214.

Pecl, G.T., E. Ogier, S. Jennings, I. van Putten, C. Crawford, H. Fogarty, S. Frusher, A.J. Hobday, et al. 2019. Autonomous adaptation to climate-driven change in marine biodiversity in a global marine hotspot. In Human adaptation to biodiversity change in the anthropocene, eds. P.L. Howard, G.T. Pecl, R.K. Puri, and T. F. Thornton, Ambio vol. 48, Special Issue. https:// doi.org/10.1007/s13280-019-01186-x.

Peters, K., L. Breitsameter, and B. Gerowitt. 2014. Impact of climate change on weeds in agriculture: A review. Agronomy for Sustainable Development 34: 707-721. https://doi.org/10.1007/ s13593-014-0245-2.

Porter, J. R., L. Xie, A.J. Challinor, K. Cochrane, S.M. Howden, M.M. Iqbal, D. Lobell, and M. I. Travasso. 2014. Food security and food production systems. In Climate change 2014: Impacts, adaptation and vulnerability. Part A: Global and sectoral aspects. Contribution of Working Group II to the Fifth Assessment Report of the Intergovernmental Panel on Climate Change, 487-533. Cambridge: Cambridge University Press.

Rodríguez Valencia, M., I. Davidson-Hunt, and F. Berkes. 2019. Social-ecological memory and responses to biodiversity change in a Bribri Community of Costa Rica. In Human adaptation to biodiversity change in the anthropocene, eds. P.L. Howard, G.T. Pecl, R.K. Puri, and T. F. Thornton, Ambio vol. 48, Special Issue. https://doi.org/10.1007/s13280-019-01176-z.

Scheffer, M. 2009. Critical transitions in nature and society. Princeton, N.J.: Princeton University Press.

Scheffers, B.R., L. De Meester, T.C. Bridge, A.A. Hoffmann, J.M. Pandolfi, R.T. Corlett, S.H. Butchart, P. Pearce-Kelly, et al. 2016. The broad footprint of climate change from genes to biomes to people. Science. https://doi.org/10.1126/science. aaf7671.

Shaw, M.W., and T.M. Osborne. 2011. Geographic distribution of plant pathogens in response to climate change. Plant Pathology 60: 31-43. https://doi.org/10.1111/j.1365-3059.2010.02407.x.

Sirami, C., P. Caplat, S. Popy, A. Clamens, R. Arlettaz, F. Jiguet, L. Brotons, and J.-L. Martin. 2017. Impacts of global change on species distributions: Obstacles and solutions to integrate climate and land use. Global Ecology and Biogeography 26: 385-394. https://doi.org/10.1111/geb.12555.

Thorn, J.P.R. 2019. Adaptation "from below" to changes in species distribution, habitat and climate in agro-ecosystems in the Terai Plains of Nepal. In Human adaptation to biodiversity change in the anthropocene, eds. P.L. Howard, G.T. Pecl, R.K. Puri, and T. F. Thornton, Ambio vol. 48, Special Issue. https://doi.org/10. 1007/s13280-019-01202-0.

Thornton, T., and N. Manasfi. 2010. Adaptation-genuine and spurious: Demystifying adaptation processes in relation to climate change. Environment and Society: Advances in Research 1: 132-155. https://doi.org/10.3167/ares.2010.010107.

Thornton, T.F., R.K. Puri, S. Bhagwat, and P.L. Howard. 2019. Human adaptation to biodiversity change: An adaptation process approach applied to a case study from southern India. In Human adaptation to biodiversity change in the anthropocene, eds. P.L. Howard, G.T. Pecl, R.K. Puri, and T. F. Thornton, Ambio vol. 48, Special Issue. https://doi.org/10.1007/s13280-019-01225-7.

Tylianakis, J., R.K. Didham, J. Bascompte, and D.A. Wardle. 2008. Global change and species interactions in terrestrial ecosystems. Ecology Letters 11: 1351-1363. https://doi.org/10.1111/j.14610248.2008.01250.x.

Van Vuuren, D.P., O.E. Sala, and H.M. Pereira. 2006. The future of vascular plant diversity under four global scenarios. Ecology and Society 11: 25.

Vasilakopoulos, P., D.E. Raitsos, E. Tzanatos, and C.D. Maravelias. 2017. Resilience and regime shifts in a marine biodiversity hotspot. Scientific Reports. https://doi.org/10.1038/s41598-01713852-9.

Wise, R.M., I. Fazey, M. Stafford Smith, S.E. Park, H.C. Eakin, E. Archer van Garderen, and B. Campbell. 2014. Reconceptualising adaptation to climate change as part of pathways of change and response. Global Environmental Change 28: 325-336. https:// doi.org/10.1016/j.gloenvcha.2013.12.002.

Yan, Y., Y.-C. Wang, C.-C. Feng, P.-H.M. Wan, and K.T.-T. Chang. 2017. Potential distributional changes of invasive crop pest species associated with global climate change. Applied Geography 82: 83-92. https://doi.org/10.1016/j.apgeog.2017.03.011.

Publisher's Note Springer Nature remains neutral with regard to jurisdictional claims in published maps and institutional affiliations.

\section{AUTHOR BIOGRAPHIES}

Patricia L. Howard $(\square)$ is a Professor at the Department of Social Sciences at Wageningen University and Research Center, and Honorary Professor at the Centre for Biocultural Diversity, School of Anthropology and Conservation, University of Kent. She is also a Coordinating Lead Author for the ongoing IPBES Global Invasive Alien Species Assessment. Her current research interests include human adaptation to biodiversity change, biodiversity tipping points, theories of human-environment relations, indigenous and local knowledge and gender and social-ecological dynamics in food systems (ethnobiology and ethnobotany). She worked for two decades in the UN System in Latin America and at FAO headquarters in Rome. Address: Department of Social Sciences, Wageningen University and Research Center, Hollandseweg 1, 6706 KN, Wageningen, The Netherlands.

Address: Centre for Biocultural Diversity, School of Anthropology and Conservation, University of Kent, Canterbury CT2 7NR, UK. e-mail: P.Howard@wur.nl

Gretta T. Pecl is a Professor at the Institute for Marine and Antarctic Studies at the University of Tasmania and the Director of the Centre for Marine Socioecology. Her research interests include ecological implications of marine climate change, human adaptation to these changes, citizen science and science communication.

Address: Institute for Marine and Antarctic Studies, The University of Tasmania, PO Box 49, Hobart, TAS 7001, Australia.

Address: Centre for Marine Socioecology, University of Tasmania, Private Bag 49, Hobart, TAS 7001, Australia.

e-mail: Gretta.Pecl@utas.edu.au 